\title{
触 New Disease Reports \\ First report of garlic rust caused by Puccinia allii in Cuba
}

\author{
E. Martínez-de la Parte ${ }^{1 *}$, P.M. Sierra Ricabal ${ }^{2}$, D. García Rodríguez ${ }^{3}$ and M.E. Lorenzo ${ }^{2}$ \\ ${ }^{1}$ Plant Health Research Institute (INISAV), Ministry of Agriculture of Cuba, Calle 110, No. 514, e/ 5th B y 5th, F. Playa, \\ Havana, P.C. 11600, Cuba; ${ }^{2}$ Cienfuegos Provincial Plant Protection Laboratory, Ministry of Agriculture of Cuba, Cuba; ${ }^{3}$ \\ Central Plant Quarantine Laboratory (LCCV), Ministry of Agriculture of Cuba, Ayuntamiento No. 231 entre San Pedro y \\ Lombillo, Plaza de la Revolución, Havana, P.C. 10400, Cuba
}

*E-mail: martinez@inisav.cu

Received: 02 Sep 2015. Published: 12 Dec 2015. Keywords: Allium sativum, Puccinia porri

Garlic (Allium sativum) is widely cultivated in Cuba with an annual production of 21,631 tonnes in 2013 (Food and Agriculture Organization, 2015). Garlic is produced by small growers and is used as a key ingredient in the preparation of traditional Cuban recipes.

During February 2014, rust symptoms were observed in a single commercial garlic field of 0.25 ha in the Cumanayagua municipality, Cienfuegos province, in the central region of Cuba. Early symptoms consisted of small (1-2 mm), circular to elongate, white flecks on leaves. As the disease progressed, these spots expanded into oblong lesions. The leaf tissue covering the lesions ruptured, and masses of yellow to orange urediniospores became visible as pustules (Fig. 1a). Telia later developed on the same leaves, resulting in black pustules (Fig. 1b). The leaves that were severely infected were almost entirely covered with pustules resulting in yellowing and premature drying. Disease incidence in the field was approximately $25 \%$ but most of the infected plants were severely damaged.

For microscopic examination, urediniospores and teliospores were scraped from dry leaves, mounted in cotton blue solution on glass slides and examined with a Zeiss Axioskop 40 microscope. For each sample, 50 spores (approximately equal numbers each of urediniospores and teliospores) from each of four leaves were measured and their dimensions determined. Urediniospores were globoid to ellipsoid, yellowish to orange in color, echinulate and measured 25-32 x 20-25 $\mu \mathrm{m}$ with a wall thickness of 1-2 $\mu \mathrm{m}$ (Fig. 2a). Telia were black, oval to elongate and non-erumpent with two-celled, brown and smooth-walled teliospores that measured 40-60 $\times 20-25 \mu \mathrm{m}$ (Fig. $2 \mathrm{~b}, \mathrm{c}$ ). Teliospore pedicels were short, hyaline and usually fractured. One-celled mesospores were not observed. Based on these morphological characteristics, the pathogen was identified as Puccinia allii

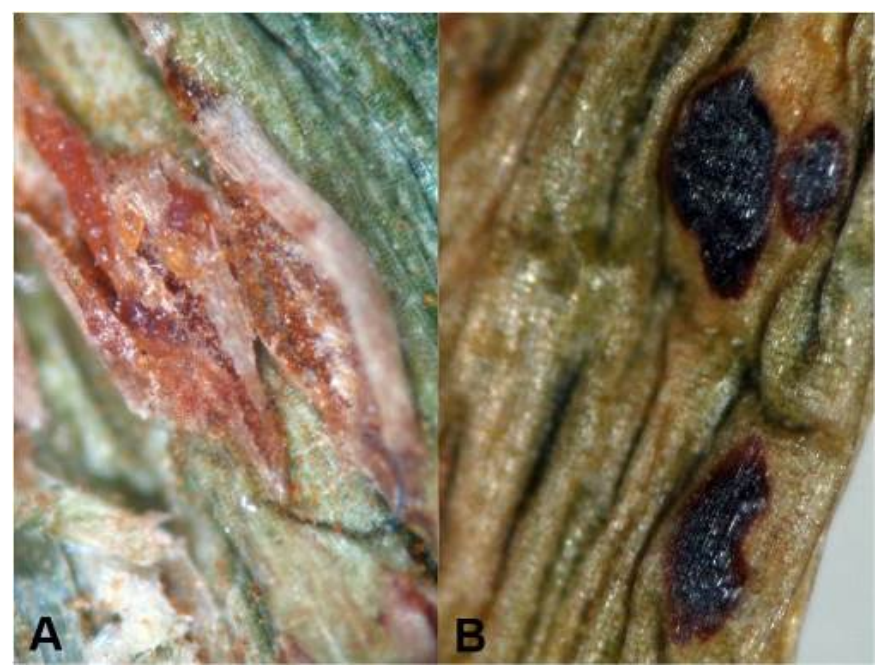

(syn. Puccinia porri) (Laundon \& Waterson, 1964; Koike et al., 2001).

This is the first report of $P$. allii infecting garlic in Cuba. The rust has been reported previously infecting onion in Cuba (Schmiedeknecht, 1984). However, since this initial report there has been no other report of $P$. allii infecting Allium crops in Cuba (Camino Vilaró et al., 2006; Farr \& Rossman, 2015).

\section{References}

Camino Vilaró M, Mena Portales J, Minter DW, 2006. Fungi of Cuba. Retrieved 11 December 2014 from

http://www.cybertruffle.org.uk/cubafung

Farr DF, Rossman AY, 2015. Fungal Databases, Systematic Mycology and Microbiology Laboratory, ARS, USDA. Retrieved 17 March 2015 from http://nt.ars-grin.gov/fungaldatabases/

Food and Agriculture Organization, 2015. Garlic harvested area and production. Retrieved 17 March 2015 from http://www.fao.org/statistics Koike ST, Smith RF, Davis RM, Nunez JJ, Voss RE, 2001.

Characterization and control of garlic rust in California. Plant Disease $\mathbf{8 5}$, 585-591. http://dx.doi.org/10.1094/PDIS.2001.85.6.585

Laundon GF, Waterson JM, 1964. Puccinia allii. C.M.I. Description of Pathogenic Fungi and Bacteria No. 52. Kew, UK: Commonwealth Mycological Institute.

Schmiedeknecht M, 1984. Charakteristik der Rostpilzflora Cubas. Wissenschaftliche Zeitschrift der Friedrich Schiller, Universität Jena 6, 765-778.

Figure 1

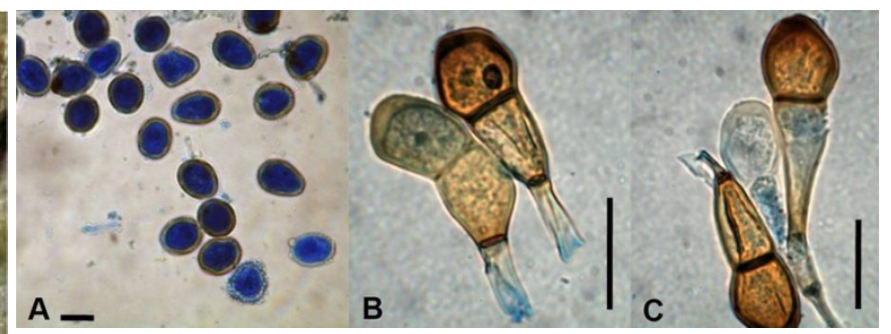

Figure 2

To cite this report: Martínez-de la Parte E, Sierra Ricabal PM, García Rodríguez D, Lorenzo ME, 2015. First report of garlic rust caused by Puccinia allii in Cuba. New Disease Reports 32, 30. http://dx.doi.org/10.5197/j.2044-0588.2015.032.030 